\title{
Conventional Angiosarcoma
}

National Cancer Institute

\section{Source}

National Cancer Institute. Conventional Angiosarcoma. NCI Thesaurus. Code C9426.

An ang iosarcoma characterized by the presence of malignant spindle endothelial cells. 